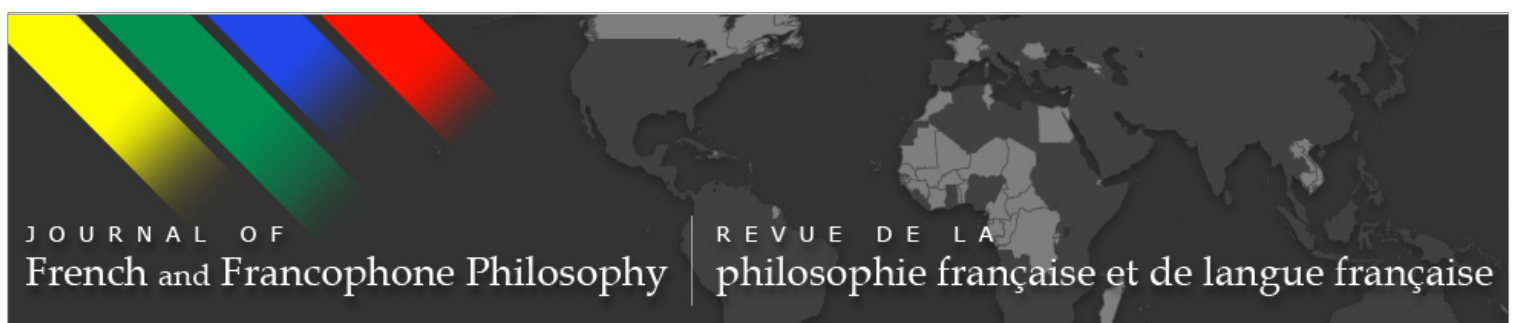

\title{
Rancièrean Atomism
}

\section{Clarifying the Debate between Jacques Rancière and Alain Badiou}

Joseph M. Spencer

Journal of French and Francophone Philosophy - Revue de la philosophie française et de langue française, Vol XXIII, No 2 (2015) pp 98-121

\author{
Vol XXIII, No 2 (2015) \\ ISSN 1936-6280 (print) \\ ISSN 2155-1162 (online) \\ DOI 10.5195/jffp.2015.691 \\ www.jffp.org
}

\section{(oc) BY-NG-ND}

This work is licensed under a Creative Commons Attribution-Noncommercial-No Derivative Works 3.0 United States License.

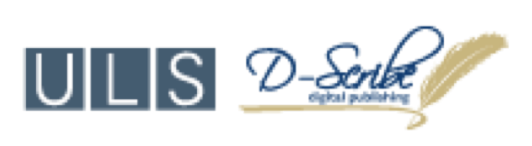

This journal is operated by the University Library System of the University of Pittsburgh as part of its D-Scribe Digital Publishing Program, and is co-sponsored by the University of Pittsburgh Press 


\title{
Rancièrean Atomism
}

\section{Clarifying the Debate between Jacques Rancière and Alain Badiou}

\author{
Joseph M. Spencer \\ Brigham Young University
}

In the late 1970s and early 1980s, perhaps due in part to the 1975 republication of Gaston Bachelard's Les Intuitions Atomistiques, ${ }^{1}$ Louis Althusser and his former student, Alain Badiou, found they had things to say about the relevance of ancient atomism to radical leftist politics. For both thinkers, whose shared debt to Bachelard had been openly avowed, the question that needed addressing concerned the relationship between atomism and structuralism. On Badiou's account, atomism canonically encapsulates the "structural dialectic," a dialecticized form of structuralism that retains from Hegel only the mystical shell, passing over the rational kernel. ${ }^{2}$ On Althusser's account, however, atomism laid the foundations of a tradition of "aleatory materialism," an entirely non-Hegelian and nonstructuralist materialism that captures the experience of political revolt. ${ }^{3}$ But because Althusser was in his last years (his writings on atomism would only be published after his death) and because Badiou was on the verge of a major transformation (his polemics against atomism would disappear as he developed the theses of Being and Event), the debate of sorts between master and student fell quickly to the wayside and has been largely ignored. ${ }^{4}$

Interestingly, another of Althusser's students would attempt in the late 1980s to venture, somewhat belatedly and quite subtly, into the same conversation regarding atomism. In his remarkable book, The Ignorant Schoolmaster: Five Lessons in Intellectual Emancipation, Jacques Rancière draws on atomistic imagery in order, like Badiou, to frame the forms of political thought that he criticizes and rejects. ${ }^{5}$ Less concerned than Badiou about deciding on the importance of Marx's Hegelian commitments or on the status of structuralism vis-à-vis politics, Rancière nonetheless takes up atomism as providing an outline of a sort of materialism that ultimately proves itself inadequate to the demands of politics. At the same time, Rancière and Badiou interpret the implications of atomism in profoundly

Journal of French and Francophone Philosophy | Revue de la philosophie française et de langue française Vol XXIII, No 2 (2015) | www.jffp.org | DOI 10.5195/jffp.2015.691 
distinct ways. It is in fact possible to see in Rancière's oblique discussion of atomism in The Ignorant Schoolmaster a similarly oblique criticism of Badiou's relationship to atomism, linking it to his more overt critical studies of Badiou published more recently. My chief aim in this paper, then, is to cast passages from The Ignorant Schoolmaster in which Rancière draws on and alludes to ancient atomism as points of important contact-and therefore of conflict-between Rancière and Badiou. Looking carefully at the differences between these two thinkers' respective investigations of the relevance of atomism to political thought allows their larger differences, both political and philosophical in nature, to be fixed more clearly.

My thesis is twofold. First, I argue that what Badiou and Rancière most obviously share in their assessments of atomism (and this links both of their treatments of atomism to Althusser's as well) is a negative judgment regarding the post-swerve constitution of the world, while what most obviously distinguishes their positions is their differing judgments regarding the pre-swerve rain of the atoms in the void-which Badiou assesses negatively and Rancière positively. Becoming quite clear both about how Badiou and Rancière respond to what comes before and after the atomistic swerve, I argue, helps to clarify an implicit response on Rancière's part to what has become Badiou's chief objection to Rancière's political theory, namely, that Rancière's conception of a "community of equals" is without intelligible content. ${ }^{6}$ Second, I argue that the fact that Badiou assesses both what comes before and what comes after the swerve as negative, while Rancière assesses only what comes after the swerve as negative (because he assesses the pre-swerve rain of the atoms in the void positively), makes clear that their most essential point of difference concerns the status of the swerve that mediates between before and after. Working through the complexities of Badiou's analysis of the swerve and uncovering Rancière's extremely subtle analysis of the swerve, I argue, helps to clarify a major aspect of what has become Rancière's chief criticism of Badiou's conception of philosophy, namely that Badiou's approach to philosophy requires that there be masters and therefore intellectual inequality. ${ }^{7}$

My primary intention here, then, is to become clearer about the dispute between Badiou and Rancière by putting a finer point principally on Rancière's contributions to that dispute, both his (implicit) response to Badiou's critique and his (explicit) criticism of Badiou's project. ${ }^{8}$ I will address these two points respectively in the second and third parts of this essay. In a first part, preceding the presentation of my arguments for my two theses, I will clarify the basic political stakes of Rancière's The Ignorant Schoolmaster, outlining the basic question to which his treatment of atomism is meant to serve as productive response.

Journal of French and Francophone Philosophy | Revue de la philosophie française et de langue française 


\section{Education and Politics}

The Ignorant Schoolmaster traces the adventures of Joseph Jacotot, the key figure for Rancière of the French workers' movement of the nineteenth century. Rancière often mentioned Jacotot in his early writings, and it was arguably in Jacotot's "Me too, I'm a painter!" that the seeds of Rancière's celebrated work on aesthetics are to be found. ${ }^{9}$ From 1818 until his death in 1840 , Jacotot was the defender of a radical program of education, "universal teaching," which proposed to put directly into the hands of the ignorant the means of their own emancipation. Much of The Ignorant Schoolmaster is dedicated to situating Jacotot's pedagogical radicalism, to revealing the important ways in which it grew out of and alongside certain developments of its era but more especially the essential ways in which it worked against the spirit of the times. The point of the book, it thus seems, is principally to contest certain approaches to questions of education. After all, the significance of the student uprisings of 1968, in which Rancière himself participated, was at stake. Althusser's appropriation of the student movement for his own work on ideology, Pierre Bourdieu's deeply influential seminars and publications on education, and even Jean-François Lyotard's investigation of the French educational apparatus all constituted rival visions of the status of education in France in the wake of May $1968 .^{10}$ Rancière's work on Jacotot's career would seem to have been his intervention in this larger conversation.

The educational emphases throughout The Ignorant Schoolmaster notwithstanding, the chief aim of the book is arguably more directly political in nature. Rancière has himself described his work from the late 1970s through the early 1990s as aimed first and foremost at "understand[ing] the power pertaining to a few words, words like 'proletarian' and 'emancipation,'" real clarity concerning which words he found especially in the writings of and controversy surrounding Jacotot and his radical pedagogy. ${ }^{11}$ In universal teaching he found, as he did in other, less directly educational pursuits among nineteenth-century French workers, "the singular phenomenon of a production of meaning that is neither the consciousness of an avant-garde instructed by science nor the systemization of ideas born out of the practice of the masses." ${ }^{12}$ In short, what Rancière works out in The Ignorant Schoolmaster is less concerned with directly intervening in the crisis of the education systems of the West than with contesting the working assumption of so much of leftist politics: the idea that ideological superstructures demand the formation of a leftist intellectual elite who have the task of distinguishing ideology from science and so of setting workers on the right path to material emancipation.

The political ramifications of The Ignorant Schoolmaster begin to materialize really only in the fourth and fifth of Rancière's five "lessons in intellectual emancipation," though the third lesson lays the groundwork for

Journal of French and Francophone Philosophy | Revue de la philosophie française et de langue française Vol XXIII, No 2 (2015) | http://www.jffp.org | DOI 10.5195/jffp.2015.691 
the elaboration of those ramifications. That third lesson makes two essential moves. First, it sets forth in outline a basic epistemology. Truth as suchrigorously distinguished from mere facts, observable states of affairs- "is a whole, and language fragments it; it is necessary, and languages are arbitrary." ${ }^{13}$ Because "there is no code given by divinity, no language of languages," 14 human beings, as speaking animals, are condemned always and only to be "circling around the truth, from fact to fact, relation to relation, sentence to sentence." ${ }^{15}$ Those who know their own intellectual capacity-and who consequently know it to be equal to that of every other human being-assume a position in orbit around the truth. ${ }^{16}$ This image of being in orbit sums up the whole of Rancière's epistemology, and, as will become clearer, it lies at the heart of his interest in atomism. Already in the third lesson, Rancière uses-rather subtly, and in a way that will have to be clarified later-the language of atomism in connection with his talk of being in orbit: "One can say, if one likes, that truth brings together. But what brings people together, what unites them, is nonaggregation. . . . People are united because they are people, that is to say, distant beings," each pursuing its own orbit. $^{17}$

The second move Rancière makes in the third lesson of The Ignorant Schoolmaster concerns what he calls "one of the canonical exercises of universal teaching": that of improvisation. ${ }^{18}$ This exercise draws deeply on the epistemology just described, since it makes of all communication-as Jacotot himself put it-“a kind of perpetual improvisation." ${ }^{19}$ As Rancière explains: "The impossibility of our saying the truth, even when we feel it, makes us speak as poets, makes us tell the story of our mind's adventures and verify that they are understood by other adventurers." ${ }^{20}$ All human communication, according to Rancière, amounts to a poetic or artistic gesture: not a transmission of knowledge, but a narrativization of one's orbit around the truth. This understanding of the implications of his basic epistemological picture allows Rancière to make his first strictly political gesture in The Ignorant Schoolmaster: "We can thus dream of a society of the emancipated that would be a society of artists." ${ }^{21}$ Where there exists a community of those who assume on the part of all their companions equal intellectual capacity, there exists a community of artists, all of them bent on improving their expressive ability so as to tell others of their own adventures in orbit about the truth. In such a community, however small, Rancière finds the seeds of collective emancipation-of a nonaggregated community of equals, to use again in a preliminary way the language of atomism introduced just above.

These two moves-outlining a nonrationalist epistemology and drawing its implications for the nature of human communication-lay the foundation for the heavy political focus of the fourth and fifth lessons of The Ignorant Schoolmaster. Here it will have to suffice to focus principally on the fourth lesson, which is where Rancière's allusions to atomism appear in 
concentrated form. ${ }^{22}$ There again Rancière focuses on drawing consequences from the epistemological picture presented in the third lesson. If truth does not decide in any direct way on debates among human beings regarding the reasons for relatively straightforward observable facts, it certainly "settles no conflict in the public place." ${ }^{23}$ Among observable facts, there is the fact of the social order-with all the equities or inequities one wishes to find in itbut there is no possible way to know, directly, that the present order either is or is not the true order of things. As Rancière summarily puts this point, "there is no political science, no politics of truth." ${ }^{24}$ As a result, conservatives and progressives alike confuse politics with the production and the maintenance of the social order. Better, they confuse community with social order and make that confusion the founding axiom of all their political theories. For Rancière, however, political engagement just is the work of maintaining the distinction between a community and a social order. ${ }^{25}$

What is at issue here is a political practice, a perpetual enactment of community such that it cannot be reduced to any social order. This Rancière makes perfectly clear at the conclusion of the fourth lesson: "There cannot be a class of the emancipated, an assembly or a society of the emancipated. But any individual can always, at any moment, be emancipated and emancipate someone else, announce to others the practice and add to the number of people who know themselves as such." ${ }^{26}$ Community, as Rancière conceives it, never crystallizes in a stable or even a semi-stable order without thereby canceling community. Community remains only so long as those making it up continue in motion, in their non-hierarchical but also non-identical orbits about the truth. If the anarchic performance of community ceases, it is always because order is restored, but order excludes the rational chaos of performance. $^{27}$ To the individual engaged in the anarchic performance of community, Rancière-following Jacotot on this point carefully-gives the name of "man," while to the individual placed within the order of a stable or semi-stable society he gives the name of "citizen." Thus Rancière can position himself against those political thinkers who regard the citizen as "the ideal man, the inhabitant of an egalitarian political heaven that masks the reality of the inequality between concrete individuals." ${ }^{28}$ He argues instead that "there is no equality except between men," while considering the citizen to be "man fallen into the land of inequality." 29

Of course, Rancière fully concedes that social orders prevail, that any given collection of human beings inevitably organizes itself as a society and thereby attempts to exclude the genuinely communal gesture. Unlike certain other thinkers of political performance or performativity, however, he does not therefore speak of a coming community, of something that must dawn only when social orders and their associated hierarchies at last crumble. Instead, he speaks of community as something that is already actual in all kinds of ways at any given moment and as something that can be actualized in all kinds of other ways at any given moment. Any act of genuine equality

Journal of French and Francophone Philosophy | Revue de la philosophie française et de langue française Vol XXIII, No 2 (2015) | http://www.jffp.org | DOI 10.5195/jffp.2015.691 
enacts community at least for a certain time. But it remains the case that any individual, however much she might enact equality and community in certain registers, always finds herself also and at the same time enmeshed in social hierarchies. For this reason, according to Rancière, every reasonable individual, being at once "man" and "citizen," has the task of "submit[ting] to the madness of being a citizen, while trying to safeguard his reason." ${ }^{30}$ This one does, Rancière argues, by regarding the social order not as a matter of truth or of reason, but rather as a kind of mystery: "He will consider the social order a mystery situated beyond reason's power, the work of a superior reason that requires the partial sacrifice of his own. He will submit himself as citizen to that which the irrationality of governments requires, refusing only to adopt the reasons given by it." ${ }^{31}$ The political task for the individual is to resist total dissolution into the strong acid of the social order, to retain a certain element of indissoluble equality in the midst of the networks of inequality.

Now, in light of this discussion, one might distinguish two political imperatives issued by Rancière to his readers, one directed specifically to individual persons (a kind of Rancièrean "Know thyself!") and the other directed specifically to cooperative or collective endeavors (a kind of Rancièrean ethics of institutionality). For the individual, the political mandate is to resist being dissolved into the social order without leaving behind the precipitate of engagement in a genuine community of equals. For the cooperative or collective endeavor, the political mandate is to resist the almost inevitable crystallization of every community into a social order that cancels the entropic movement of a mobile solution. Of course, the chemical images I have used in formulating these two imperatives conflict with one another, since the first figures dissolution as what must be resisted (through precipitation) but the second figures dissolution as what must be sustained (against crystallization). That is, in each of the images a certain antagonism between the mobility of a liquid and the rigidity of a solid plays a central role, but liquid mobility in the one figures the irrationality of every social order while in the other it figures the anarchy of every community of equals. Perhaps, in a general way, this conflict between images underscores the instability or ambiguity of every image, marking what might well be considered the danger of using chemical-that is, atomistic-imagery to figure concrete political claims. Yet, in a more specific way, this conflict between images helps to fix quite productively the essential distinction Rancière draws in organizing his political thought. Irrationality, a feature of every social order with its inequities, must be distinguished rigorously from anarchy, a feature of every community of equals. If community and social order are to be rigorously distinguished, it is necessary first to distinguish rigorously irrationality and anarchy.

Crucially, Rancière uses highly specific and carefully developed imagery to make these distinctions in full rigor: that of atomism. And, just as

Journal of French and Francophone Philosophy | Revue de la philosophie française et de langue française 
crucially, he does so without introducing any conflict, however instructive, into his use of the relevant images. With relevant preliminary considerations out of the way, it is possible now to turn directly to Rancière's uses of atomism in The Ignorant Schoolmaster, and to develop the ways in which those uses serve to clarify what has since become an ongoing debate-both philosophical and political—between Rancière and Alain Badiou.

\section{Before and After}

In passages mentioned above, the first way in which Rancière draws on the imagery of atomism has already made an appearance. By criticizing the notion that "truth brings together" and by arguing instead on behalf of "nonaggregation," 32 Rancière begins his assessment of atomism by figuring the constituted world(s) of the atomists as something negative. To the extent that the most ancient of the atomists were cosmologists like so many of their pre-Socratic companions, the first motivation for their doctrine was to account for the world as experienced by human beings-that is, in its relative (but nonetheless dynamic) consistency. There is no evidence in the extant fragments of the most ancient atomists that they were particularly dissatisfied with the present constitution of the world, but they nonetheless rejected the idea of the world's necessity. ${ }^{33}$ This move alone provided Louis Althusser, Badiou's and Rancière's common master (against whom each rebelled in his own way), with motivation enough to find political relevance in the atomistic cosmology. ${ }^{34}$ The sheer conviction that the world need not be as it is, whether or not such an ontology is rightly coupled with the political convictions and militant commitments that would help to alter the world, makes the atomists relevant to any thinker searching for an adequate Marxist ontology. Rancière, along with Althusser and also Badiou, can be said to develop the atomist suspicion regarding the necessity of the constituted cosmos into a fully negative assessment of every constituted social order. Because a social order is what can only be arbitrary, the social order can productively be thought along the lines of the atomists' constituted cosmos.

At first, however, Rancière presents the social order less exactly as the constituted cosmos of the atomists' ontology than as the result of every materialization of intelligence-every reduction, for instance, of minds to brains. ${ }^{35}$ Drawing on a passage from a posthumously published essay by Jacotot simply titled "Politics," Rancière argues that the secret to sustaining the act by which emancipation is effected is to ensure that intelligences are not "submit[ted] . . . to the laws of any grouping, [namely] those of matter." ${ }^{36}$ (The key sentence from Jacotot's text is as follows: "In matter, a unique force, gravity, animates mass and molecules; but in the class of intellectual beings, intelligence directs individuals alone; their union is subject to the laws of matter." $)^{37}$ In language woven of both atomist imagery and the imagery of the orbit of an intelligence around the truth, Rancière

Journal of French and Francophone Philosophy | Revue de la philosophie française et de langue française Vol XXIII, No 2 (2015) | http://www.jffp.org | DOI 10.5195/jffp.2015.691 
claims that whenever the spiritual intelligence is treated as a material thing, "the free orbit of each intelligence around the absent star of the truth, the distant flight of free communication on the wings of the word, is found to be thwarted, diverted by universal gravitation toward the center of the material universe." ${ }^{38}$ Here, following Jacotot, Rancière claims that the aggregation of atoms of intelligence in a social order can happen only when one makes of "each intellectual unity" something "necessarily inert and without intelligence." ${ }^{39}$ At least at first, what receives such a strongly negative assessment from Rancière seems not to be simply the atomists' constituted cosmos, the coherence of a systematic order, but rather the whole of atomism's materialist commitments, its reduction of all things to mere matter. To the extent that atomism commits one to the reduction of every spiritual principle (such as intelligence or mind) to materiality, it would seem to work against the deepest commitments of Rancière's project. To that same extent, then, it would seem that Rancière assesses negatively not only the constituted worlds of which the atomists spoke, but also atomism as a whole.

If this were the case, it would prove far more difficult than it actually is to place Badiou and Rancière in productive conversation on atomism. As it turns out, however, Rancière does not dismiss materialism per se, despite what might be suggested by his approving quotation of Jacotot's words. Rather, and fascinatingly, he presses into service not only Jacotot's words quoted above, which suggest that atomism's materialist commitments leave little room for the flight of intelligence, but also another passage from elsewhere in Jacotot's corpus (specifically in a book on law or right) where atomistic imagery is used more affirmatively. ${ }^{40}$ There, in a chapter entitled "And," Jacotot again argues that "there is nothing of reason" in matter, "and there cannot be any." ${ }^{41}$ But he there nonetheless explores in a thought experiment what might be said of collectives of material "human corpuscles" if they "were reasonable." ${ }^{42}$ Jacotot argues that, "then, under a unique impulsion, nations and the human species would follow a uniformly straight line, smoothly, without deviation, without aberration." ${ }^{43}$ This image derives unmistakably from ancient atomism, particularly as it developed under the influences of Epicurus and then Lucretius. For these ancient atomists the atoms in the void initially fall in straight parallel lines, whereas for their predecessors the atoms initially move circularly in great vortices. ${ }^{44}$ Jacotot seems to suggest that, to whatever extent it might be possible to conceive of materialized intelligences without condemning them to the aggregating force that produces social order, ancient atomism can be accommodated.

This Rancière takes over from Jacotot, and it allows him the possibility of embracing materialism without compromising his political doctrine. More importantly, perhaps, it leads him to assess one part of the atomists' picture quite positively even as he-along with Althusser and Badiou-assesses

Journal of French and Francophone Philosophy | Revue de la philosophie française et de langue française 
another part of the same picture quite negatively. While it is necessary to criticize the social order, figured by the atomists' constituted cosmos, it is possible to draw approvingly on the rain of the atoms in the void that, according to certain of the ancient atomists, preceded the constitution of the cosmos. And in that image Rancière seems to find a particularly well-suited figure for his community of equals. In the undeviating fall of the atoms downward in the infinite void, none of them swerving to create the series of collisions that ultimately produce the ordered cosmos, Rancière sees what might be the best and most productive image of individual intelligences, each in her unique orbit about the absent star of truth.

It is thus that Rancière-unlike others-provides a positive assessment of what comes before the constitution of the cosmos in the atomist picture, even as he-like others-provides a negative assessment of what comes after the constitution of the cosmos in the same picture. (Importantly, Rancière has more recently made the same move, albeit slightly more implicitly, in a brief use of the language of atomism to critique every social order. $)^{45}$ And it is in this distribution of positive and negative assessments that Rancière's approach to atomism can be said to differ most clearly from that of Alain Badiou. Whether it would be appropriate to assume that Rancière wrote out his brief comments on atomism in The Ignorant Schoolmaster in direct response to Badiou's discussion of atomism in Theory of the Subject, the latter appearing in print some five years before the former, much can be learned from bringing the two into conversation. To do so, it will of course be necessary to say at least a few things about Badiou's approach to atomism.

For Badiou in the late 1970s - that is, before he struck on the pathway that led to his fully mature project, the first installment of which appeared the year after the publication of The Ignorant Schoolmaster ${ }^{46}$-atomism provides the outline of what he calls the structural dialectic, to be distinguished from the materialist dialectic. ${ }^{47}$ Both of these dialectics he finds operative in Hegel, with the structural dialectic there compromising again and again the materialist dialectic. The chief aim of the whole first half of Theory of the Subject is to disentangle the materialist dialectic from the structural dialectic so as to provide both Marxist theory and Marxist practice with needed clarity after the dissipation of French Maoism. The chief distinction between the two dialectics, on Badiou's account, is that the materialist dialectic organizes the logic of a periodizing history, of a history of successive epochs of struggle between strongly contradictory terms, while the structural dialectic organizes the logic of a circular history, of a history that culminates in restoring and then securing a pre-dialectical indifference between the terms that set the dialectic in motion. ${ }^{48}$ In commenting on atomism, then, Badiou aims to show how it models the manner in which the structural dialectic systematically reworks the core contradiction underlying

Journal of French and Francophone Philosophy | Revue de la philosophie française et de langue française Vol XXIII, No 2 (2015) | http://www.jffp.org | DOI 10.5195/jffp.2015.691 
the materialist dialectic in order to establish, to pursue, and finally to arrive at a totalized and totalizing end.

Essential to Badiou's conception of the materialist dialectic is its rootedness in contradiction, in the sort of irreparable contradiction that disallows the teleological closure of a dialectical process and therefore grounds a strictly periodizing history. For such a contradiction to obtain, according to Badiou, some asymmetrical correlation between two distinct terms must exist. Moreover, the difference between the two terms must be strong (that is, "one of the terms affirms itself only by destroying the other"), the correlation between them must be processual (that is, the two terms must engage in "the struggle of opposites"), and the asymmetry must be capable of inversion (that is, "the essence-in-becoming of the asymmetry is the inversion, not the invariance, of position"). ${ }^{49}$ Strong difference, processual correlation, and reversible asymmetry together make up contradictions of the sort that set material dialectics in motion. And, interestingly, they can all three be found, on Badiou's account, in the parallel rain of the atoms in the void before the deviation that leads to the constitution of the ordered cosmos. The atomists, as thinkers of how the rain of the atoms could be interrupted so that a (relatively) stable world could come into being, were those who accounted for the possibility of dismantling contradiction by canceling the strong difference between terms that grounds contradiction as such. They sought the means to "bring back a strong (qualitative) difference to its bare bones, the weak difference, or the difference of position, which undergirds it," so that whatever asymmetrical correlation might still hold has no material force in the dialectic. ${ }^{50}$

The way I have summarized Badiou's account of atomism to this point might sound as if he were approving of the parallel rain of the atoms in the void, perhaps in something like the way that Rancière, following Jacotot, assesses that pre-cosmic situation positively. There, before the erection of a (relatively) stable cosmos, Badiou finds strong contradiction and, therefore, all the trappings of the materialist dialectic. The situation is more complicated, however. Badiou indeed does find the founding contradiction of a materialist dialectic operative in the rain of the atoms in the void, butas I will have to make fully clear in the next section of this paper-he also finds there a certain lack of torsion necessary to founding a fully adequate Marxist ontology. It is ultimately elsewhere in the atomist picture that Badiou locates the figure for radical politics.

How, though, does Badiou find contradiction figured in the parallel rain of the atoms in the void, before the transformation that leads eventually to the constitution of a cosmos? Simply put, he turns to Hegel's Science of Logic. Of course, strong difference is not difficult to locate in atomism, with or without Hegel, who speaks of the "complete externality" of atoms and void to one another. ${ }^{51}$ In a similar vein, Badiou simply asks, "What difference can be stronger than the one between atoms and the void" -

Journal of French and Francophone Philosophy | Revue de la philosophie française et de langue française 
between "the discrete multiplicity of matter" and "the infinite continuity of the nothing" ${ }^{52}$ What Badiou draws from Hegel, rather, is the idea that in the ancient atomists themselves can be found a processual correlation and a reversible asymmetry in addition to strong difference. Left in their "complete externality" to one another, atoms and the void would be strongly different from each other but never in contradiction. But Hegel understood the atomists, since they "derive[ed] the infinite variety of the world" from a "simple antithesis," to have seen some kind of dialectical interplay at work between atoms and void. ${ }^{53}$ The key, as Badiou notes, is to see that "the void engenders the movement of the atoms." ${ }^{54}$ In Hegel's own words, the ancient atomists worked out "a speculative determination" by finding in the void "the source of movement, which is an entirely different relation of the atom and the void from the mere juxtaposition and mutual indifference of these two determinations." 55 That is, as Hegel puts it, "the void is [for the atomists] the ground of movement only as the negative relation of the one [the void] to its negative [the atoms]." ${ }^{56}$ The negative, the motor of the Hegelian dialectic, organizes the relationship between the atoms and the void of ancient atomist thought, such that some kind of dialectic-with processual correlation and reversible asymmetry-operated in their cosmology.

But if Badiou finds full-blooded contradiction at work in the precosmic rain of the atoms in the void, why does he not assess it quite positively, perhaps finding in it a figure for, say, mass movements, to which he gives so much attention in Theory of the Subject? Given his proclivity for finding in formal thought figures for political experiences, might he not argue that the rain of the atoms in the void figures the march of so many clear-sighted militants that eventually, only when deviations to the right and to the left intervene and slow the march of the mass movement, coalesces into state-bound consensus? Importantly, Badiou makes no such move. And even before coming to a fuller clarification of this point in the next section of this paper, it is possible to identify something of what the pre-cosmic situation of the atoms lacks for Badiou. He puts the point this way: "This 'movement' [in parallel in the void] is perfectly null, for lack of a reference point with which to mark it-the simultaneous and isotropic vection of an infinity of atoms, without the shadow of a doubt, being equivalent to their absolute immobility. Once again, nothing happens." ${ }^{57}$ In other words, the undeviating fall of the atoms in the void, "all mov[ing] together eternally and according to parallel trajectories at variable speeds," ${ }^{28}$ is a figure for mere nature bereft of any event-nature prior to or apart from the torsion of history that would fully realize what in it remains only potentially dialectical. ${ }^{59}$ Like Rancière, Badiou refuses to assess positively the congealed worlds with which the atomist cosmology concludes its story, but unlike Rancière, he finds in the essentially history-less or non-evental pre-cosmic rain of the atoms in the void something equally unsatisfying.

Journal of French and Francophone Philosophy | Revue de la philosophie française et de langue française Vol XXIII, No 2 (2015) | http://www.jffp.org | DOI 10.5195/jffp.2015.691 
Where Badiou assesses both the pre-cosmic and the cosmic moments of atomism negatively, each for distinct reasons, Rancière assesses only the cosmic moment of atomism negatively, reserving the possibility of appropriating approvingly the pre-cosmic moment for his own purposes. This constitutes the clearest, the most overt difference between Badiou and Rancière on atomism. What makes this an important and especially interesting point, however, is the fact that Rancière's interest in the precosmic rain of the atoms in parallel in the void, at least as an instructive figure, can be read as providing him with a ready answer to what has become Badiou's most consistent critique of Rancière's political theory. According to Badiou, Rancière's notion of a community of equals, irreducible to any social order, is bereft of content. In his own words, "the theme of the community of equals . . . suggests either a totality without master . . . or an equality which is held together under a pure empty mark of mastery, whose vertical absence provides the foundation for the horizontal bond." 60 At best, according to Badiou, this notion entails "the idea of a shared mastery without a master position." ${ }^{61}$ But Rancière's image of the community of equals as so many atoms falling in parallel in the void clarifies that what is at issue in his conception is not a horizontal bond but a parallel of trajectories.

Moreover, because Rancière provides, in The Ignorant Schoolmaster especially, a strictly delineated operation (a "device," Rancière calls it) by which such parallel trajectories are launched, ${ }^{62}$ and because that operation employs a clearly defined "master position" and the conditions of its occupation, Badiou seems simply wrong to claim that Rancière works with "the idea of a shared mastery without a master position." Rancière describes Jacotot's students as having "learned without a master explicator, but not, for all that, without a master." ${ }^{63}$ Although it would be distracting here to pursue the details at length, it must be said that the figure of the ignorant schoolmaster-or, reflecting the French somewhat more directly, the ignorant master-allows Rancière to construct the concept of a community of equals without appealing to any such self-canceling conception as Badiou attributes to him. ${ }^{64}$ And this point is not without its atomist bearings. Late in The Ignorant Schoolmaster, Rancière compares the operation of the ignorant master to an electric charge between otherwise distant atoms, the effect of which is to launch the atoms in their undeviating parallel trajectories. Those who pursue intellectual emancipation "may awaken that entirely new energy that fascinated lovers of liberty, that power without gravity or agglomeration that is propagated in a flash by the contact between two poles. Whoever forsakes the workings of the social machine has the opportunity to make the electrical energy of emancipation circulate." 65

There is thus much that Badiou seems to miss in Rancière's conception of the community of equals. And it is significant that what most tellingly helps to clarify that conception derives from Rancière's investment in certain

Journal of French and Francophone Philosophy | Revue de la philosophie française et de langue française 
atomistic images. But this point can be developed further by turning to a more subtle point of distinction between Badiou and Rancière as regards atomism, one that marks their distance more radically.

\section{Between}

As ancient atomism developed from Leucippus and Democritus to Epicurus and Lucretius, attention came to focus on exactly how the precosmic motion of the atoms gives way to the process of agglomeration that brings a cosmos into being. While, chiefly because of the way Rancière draws on atomism, the focus in this essay has to this point been on the "before" and the "after" of the atomist cosmology, the "between" of transformation deserves attention. As noted before, Badiou finds the atomist picture politically productive not in the pre-cosmic motion of the atoms but elsewhere, thus distinguishing his approach from Rancière's. But where he finds the atomists to have fixed something of genuine political importance is in the so-called swerve, the deviation of some atom or atoms from its or their otherwise straight trajectory in the void. It is this rather than the rain of the atoms that he takes as a figure for "the mass movement," which catalyzes "the evental concatenation that is called history." 66 For his part, however, Rancière seems at first to say more or less nothing about the swerve, taking the sheer difference between the constituted cosmos (as figure for the constituted social order) and the pre-cosmic rain of the atoms (as figure for the community of equals) to be sufficient to illustrate the stakes of his political theory. A closer look, however, reveals that Rancière does indeed have something to say about the swerve, albeit in the form of a negative assessment, over against Badiou's positive assessment.

The notion of the swerve itself seems relatively straightforwardstraightforward enough, in fact, to draw the ridicule of critics. Cicero famously mocked Epicurus as follows:

Then this clever fellow, when it occurred to him that if they [the atoms] all moved directly down and, as I said, in a straight line, it would never come about that one atom could make contact with another and so . . . he introduced a fictitious notion: he said that an atom swerves by a very little bit, indeed a minimal distance, and that in this way are produced the mutual entanglements, linkages, and cohesions of the atoms as a result of which the world and all the parts of the world and everything it are produced. ${ }^{67}$

From Cicero's perspective, "the swerve itself is made up to suit [the atomist's] pleasure," serving to patch up a rather embarrassing oversight, and Epicurus only described it as "without a cause" in order to maintain, entirely unconvincingly, consistency regarding the basic principles of the world (atoms and void). ${ }^{68}$ Karl Marx, for his part, was less than impressed

Journal of French and Francophone Philosophy | Revue de la philosophie française et de langue française

Vol XXIII, No 2 (2015) | http://www.jffp.org | DOI 10.5195/jffp.2015.691 
with Cicero's simplistic dismissal: "The declinatio atomorum a via recta [deviation of the atoms from the straight line] is one of the most profound conclusions," he wrote in his early notebooks on atomism. "Cicero might well laugh at it, he knew as little about philosophy as about the president of the United States of North America."69 Marx famously developed a (Hegelian) dialectical interpretation of the swerve at great length in his doctoral thesis. ${ }^{70}$ Badiou clearly follows Marx in this regard, finding extremely subtle dialectical insight operative in the ancient account of the swerve. But for Badiou, the swerve also quivers at the border between the structural and the materialist dialectics. In the hands of the atomists themselves, ultimately, the swerve serves principally to "filter the strong difference into a weak difference," that is, to replace genuine heterogeneity (atoms and void) with "a homogeneous combinatory space, wherein a process becomes composed with terms of the same kind." ${ }^{71}$

Following Marx's dialectical reading, Badiou argues that the swerve of an atom constitutes an exception with respect to the law of pre-cosmic atomistic motion. And he insists that this insurrectionary status of the swerving atom "marks the void, since [this atom in particular] is affected by [the void] in a different way and not just in its generality as atom." ${ }^{\prime 2}$ Better put, the swerving atom becomes something like the proper name of the void, the "atomistic designation of the void itself," inasmuch as it uniquely (among atoms) relates to the void by deviating from the straight line. ${ }^{73}$ But as the bearer of the name of the void, the deviating atom relocates the absolute heterogeneity between atoms and void to a position among the atoms themselves, with one (the deviating atom) serving as the figure of the void and the others (the undeviating atoms) serving still as atoms. The strong difference between atoms and the void here becomes a weak difference, between one sort of atom (which names the void) and another sort of atom (which does not name the void). The void, in the meanwhile, "has dropped out.", 74

This first dialectical move, however, does not spell disaster in and of itself. Indeed, Badiou finds in the insurrectionary swerve of the atom that designates the void a figure for every mass uprising, the revolt from within the constituted order. What marks the structural commitments of the ancient atomistic dialectic, according to Badiou, is the way it goes on to insist that not only the void but the very trace of the void-the swerving atom-must disappear (as vanishing cause of the formation of the cosmos). This the atomists accomplished by claiming that the swerve has no cause, that "no atom should ever be mappable as deviant, in any combination of atoms whatsoever, even though the existence of deviation conditions the very existence of a combinatory."75 For the atomists with their structural investments, the insurrectionary cause born of chance must be erased, so that structure prevails. If, however, the swerve is handled differently-not erased but rendered consistent_-its insurrectionary status prevails over structure and 
genuine political revolution takes place. ${ }^{76}$ In the place of anxiety about the insurrection that one pretends has not happened, one inserts the courage necessary for pursuing the consequences of the chance happening of the uprising. And in the place of submission to the superegoic force that underlies the law of the situation, one inserts real commitment to the justice that should govern the process of developing consistency within the mobilized masses.

For Badiou, then, the political relevance of the atomists lies in the way they recognize-even if they subsequently attempt to conceal it-the insurrectionary force marked by the swerve, the interruptive flash of the void among the atoms. Where that force or that flash, and therefore the strong dialectical contradiction it harbors, finds subjects prepared to pursue its destructive consequences, the structural tendencies of atomism fall away, and a materialist periodizing dialectic unfolds. In the swerve, fully granted its interruptive position between the pre-cosmic motion of the atoms in the void and the full constitution of cosmic order, Badiou finds a figure for robust radical political subjectivity. And although he has not used the set of images provided by ancient atomism in his more recent work, it is precisely this picture of things that still prevails, with the swerve now figured by the concept of the event. ${ }^{77}$ But what, for his part, does Rancière find in the swerve? Given the manner in which he assigns a positive value to the precosmic rain of the atoms in parallel in the void, it should be unsurprising that his assessment of the swerve, only subtly hinted at in The Ignorant Schoolmaster, is ultimately negative. Put in a nutshell, Rancière's position is that the swerve marks the failure of the community of equals, the beginning of the process of agglomeration that brings into being a social order with its hierarchies.

I have already made clear that Rancière draws both his negative assessment of the atomists' cosmos and his positive assessment of the atomists' pre-cosmic rain from the writings of Jacotot. He does not seem to have found in Jacotot, however, any clear assessment of the swerve that marks the beginning of the process that leads from the one to the other. This he provides himself, rather. I want to suggest that Rancière works out his assessment of the swerve when he assigns to the gesture that disrupts the equality of intelligence and therefore the community of equals the name of distraction. Although he never makes fully clear the connection between this choice of words and his interest in atomism in The Ignorant Schoolmaster, it is fully appropriate that the term brings together Rancière's attempts to describe the work of an intelligence under the tutelage of a will and the atomistic imagery of the atoms' rain, their diversion or distraction, and their agglomeration. And it should be noted that Rancière first makes distraction a theme in close connection with his analysis of Jacotot's two passages on atomism. It is there, for instance, that he describes "simple distraction" as, rather suggestively, "original sin."78

Journal of French and Francophone Philosophy | Revue de la philosophie française et de langue française Vol XXIII, No 2 (2015) | http://www.jffp.org | DOI 10.5195/jffp.2015.691 
In order to make sense of distraction, however, one should turn to earlier parts of the book. Already in the second lesson, Rancière assigns the name of "attention" to "the act that makes an intelligence proceed under the absolute constraint of a will." ${ }^{79}$ When one pays attention, one fully mobilizes her intelligence-equal to that of all others-through her will, whether her will has enough force on its own to accomplish the mobilization or whether her will has to be propped up by the imposition of the will of an emancipatory master. ${ }^{80}$ Attention thus arises where the will removes intelligence from every assumed hierarchy, from every social order, in order to set it quite freely to work on the world. "Attention" is a Rancièrean name for the rain of the atoms in parallel trajectories in the void. Distraction, in turn, arises when attention flags, when the will's constraint releases itself and allows an intelligence to turn from its task to self-conscious contemplation of its place in a socially-determined hierarchy. "Distraction" is thus a Rancièrean name-perhaps the Rancièrean name-for the swerve that interrupts the parallel rain of the atoms in the void and begins the process of agglomeration that results eventually in a social order, with all its inequities. Distraction is the origin of the social order. It is, as Rancière says, the "original sin," the work of the subtle serpent who disrupts the paradise of the community of equals to lay the foundations for the world of inequity and oppression, the world where the threat of death leads to every sort of evil.

If, as Rancière puts it, "there need only be distraction for intelligence to give way, for it to be overcome by the gravitation of matter" and so to fall from its orbit or to be diverted from its parallel motion with all other atoms in the void, ${ }^{81}$ it could not be clearer that the swerve is, for Rancière, the principal evil. Far from being a figure for political insurrection, as it is in Badiou, it serves in Rancière's thought as a figure for the failure of every political insurrection, the dissipation of every "logical revolt." ${ }^{82}$ Rather than marking the occurrence of chance in an otherwise total order, the swerve marks for Rancière the slide from the anarchy of the atomistic rain in the void to the irrationality of the social order. Where the purified mastery of emancipation, the direct relationship of will to will without any admixture of intellectual hierarchy, holds sway, no deviation from the community of equals occurs. But where such mastery, whether inter- or intrapersonal in nature, flags, intelligences become distracted, and the social order supplants the community of equals.

Although this difference between Badiou and Rancière in their respective appropriations of atomism more easily escapes notice than that explored in the previous section, it should be said that it is more significant than the other-and certainly more telling. Only here does it become quite clear that both Rancière and Badiou mean to find in atomism some figure for the revolt of the masses, but that they entirely disagree about where that figure is to be found in the atomists' cosmological picture. What Badiou 
rejects as an image of historyless nature Rancière takes up as an image of the community of equals in anarchic but rational revolt. And what Rancière rejects as an image of irrational distraction and concession to the prevalence of social order Badiou takes up as an image of the mass revolt that opens onto the possibility of just transformation. What marks their strongest point of difference concerns the question of whether the swerve figures resistance to suffocatingly strict order or whether it figures the collapse of resistance to suffocatingly strict order.

This helps in an important way to clarify Rancière's ready response to Badiou's criticism, discussed already in the conclusion to the preceding section of this paper. Because a specific operation of mastery-albeit never of intellectual mastery-proves necessary to ward off the distraction that undermines the community of equals, it seems Badiou is simply wrong to accuse Rancière of presenting a political picture of "a shared mastery without a master position." ${ }^{83}$ More importantly, however, this difference of opinion regarding the political relevance of the atomistic swerve helps to clarify Rancière's own critique of Badiou, worked out explicitly in much more recent publications. The essence of Rancière's criticisms lies in his accusation that Badiou consistently attempts to curb the link between art as understood since the mid-eighteenth century and mass politics. Regarding art and politics as distinct truth procedures and then assigning to philosophy the task of articulating that distinction, Badiou grants to philosophers a position of intellectual mastery that renders the political significance of the individual's orbit around the truth inaccessible to that same individual. ${ }^{84}$ This reinstalls, against all of Badiou's radical political intentions, the intractable force of the social order, according to Rancière, because it grants legitimacy to the same sense of intellectual hierarchy that undergirds the idea of social order as such.

How, though, is this clarified by the debate of sorts between Badiou and Rancière on the nature of the atomistic swerve? For both Badiou and Rancière, the swerve marks a moment of non-reason, of the unaccountable as such. And both insist that whatever is genuinely politically productive must bear within itself an essentially rational moment. What ultimately distinguishes their respective approaches to the swerve is the way each regards the relationship between the unreason of the swerve and the reason of true politics. For Badiou, the moment of reason comes in the process of rendering consistent the unreason of the insurrection. It comes, in other words, in the reason-driven process of giving to the revolt of the masses consistency enough to produce genuine transformation, genuine revolution. For that reason, Badiou makes the atomistic swerve the figure of insurrection, which must be rendered consistent in a separate and subsequent process. For Rancière, however, the moment of reason lies within the (logical) revolt itself, the insurrection being nothing other than the mobilization of (equal) intelligence by the will. It comes, in other words,

Journal of French and Francophone Philosophy | Revue de la philosophie française et de langue française

Vol XXIII, No 2 (2015) | http://www.jffp.org | DOI 10.5195/jffp.2015.691 
in the anarchy of thought, entirely inconsistent and irreducible to any social ordering, even in transformation or revolution. For that reason, Rancière makes the atomistic swerve the figure of the insurrection's failure, the dissipation of the revolt as reason gives way to unreason.

Importantly, for each thinker, some figure of mastery serves to ensure that reason has its rightful place in relationship to unreason. But the figure of mastery is distinct in each case. For Badiou, the master appears in the form of the thinker who, in the wake of insurrection and its unreason, takes up from a position of intellectual superiority the task of rendering the insurrectionary cause consistent enough to have real purchase on the situation in which it had its origins. For Rancière, the master appears in the form of the emancipator who instigates insurrection and its reason by setting her own intelligence aside to establish a hierarchical linkage of wills that frees up otherwise servile intelligences. Both thinkers ultimately work at cross purposes with the atomists, whether because-as with Badiou-they satisfy themselves with dialectically erasing rather than rendering consistent the swerve that ontologically figures political insurrection, or whether because-as with Rancière-they privilege rather than contest the swerve and the cosmic constitution it sets in motion over the pre-cosmic rain that ontologically figures logical revolt.

\section{Conclusion}

In the end, it must of course be said that Badiou and Rancière approach and appropriate atomistic thought quite differently. Yet certain similarities in their understandings make it possible for close comparative work on their uses of atomism to illuminate the debate that has organized their ongoing relationship. Both see in the atomists' constituted cosmos a figure for the consistency of situations, for social orders as such. And both see in the atomists' swerve a certain moment of essential non-reason that plays some role in leading to the production of any particular social order. What ultimately distinguishes them here as elsewhere is whether they regard political insurrection as rational or irrational in nature, and therefore how they understand the role of mastery to see that insurrection accomplishes genuinely politically productive aims. Should the atomistic swerve figure insurrection or its failure? Is revolt logical, or is it the illogical par excellence? This, it seems, is the central question of what has rightly been called, recently, the French philosophical tradition of "left atomism."

\footnotetext{
${ }^{1}$ See Gaston Bachelard, Les Intuitions atomistiques (essai de classification) (Paris: Vrin, 1975; originally Paris: Boivin, 1933).
}

Journal of French and Francophone Philosophy | Revue de la philosophie française et de langue française Vol XXIII, No 2 (2015) | http://www.jffp.org | DOI 10.5195/jffp.2015.691 
2 See Alain Badiou, Theory of the Subject, trans. Bruno Bosteels (New York: Continuum, 2009), 53-73.

${ }^{3}$ See Louis Althusser, Philosophy of the Encounter: Later Writings, 1978-1987, ed. François Matheron and Oliver Corpet, trans. G. M. Goshgarian (New York: Verso, 2006), 163-207.

${ }^{4}$ I have provided a preliminary assessment of the relationship between Badiou and Althusser in Joseph M. Spencer, "Left Atomism: Marx, Badiou, and Althusser on Greek Atomism,” Theory \& Event 17.3 (September 2014).

5 See especially Jacques Rancière, The Ignorant Schoolmaster: Five Lessons in Intellectual Emancipation, trans. Kristin Ross (Stanford: Stanford University Press, 1991), 75-99.

${ }^{6}$ For this critique, see especially Alain Badiou, Metapolitics, trans. Jason Barker (New York: Verso, 2005), 107-13.

${ }^{7}$ For this critique, see especially in Jacques Rancière, The Politics of Literature, trans. Julie Rose (Malden, MA: Polity, 2011), 183-205; and Jacques Rancière, Aesthetics and Its Discontents, trans. Steven Corcoran (Malden, MA: Polity, 2009), 63-87.

${ }^{8}$ A very helpful and deeply astute introduction to the dispute between Badiou and Rancière can be found in Bruno Bosteels, The Actuality of Communism (New York: Verso, 2011).

${ }^{9}$ See Rancière, The Ignorant Schoolmaster, 64-73. For the original discussion in Jacotot's own writings, see J. Jacotot, Enseignement Universel: Langue Maternelle (Paris: Librarie spéciale de l'enseignement universel, 1834), 158-59.

10 See Pierre Bourdieu and Jean-Claude Passeron, Reproduction in Education, Society and Culture, 2nd ed., trans. Richard Nice (London: Sage Publications, 1990); and Jean-François Lyotard, The Postmodern Condition: A Report on Knowledge, trans. Geoff Bennington and Brian Massumi (Minneapolis: University of Minnesota Press, 1984).

11 Jacques Rancière, "The Use of Distinctions," in Dissensus: On Politics and Aesthetics, ed. and trans. Steven Corcoran (New York: Continuum, 2010), 216.

12 Rancière, "The Proletarian and His Double, Or, The Unknown Philosopher," in Staging the People: The Proletarian and His Double, trans. David Fernbach (New York: Verso, 2011), 27-28.

${ }^{13}$ Rancière, The Ignorant Schoolmaster, 60.

${ }^{14}$ Rancière, The Ignorant Schoolmaster, 62.

${ }^{15}$ Rancière, The Ignorant Schoolmaster, 59.

Journal of French and Francophone Philosophy | Revue de la philosophie française et de langue française Vol XXIII, No 2 (2015) | http://www.jffp.org | DOI 10.5195/jffp.2015.691 
${ }^{16}$ According to Rancière (see The Ignorant Schoolmaster, 57), this self-knowledge is a matter of avoiding two "fundamental lies," the one that proclaims truth directly knowable, and the one that proclaims the impossibility of coming into any real relationship with truth. Rancière thus positions his own epistemology against both modern and postmodern rationalism-without thereby falling into a kind of naïve empiricism.

${ }^{17}$ Rancière, The Ignorant Schoolmaster, 58, emphases in original.

${ }^{18}$ Rancière, The Ignorant Schoolmaster, 64.

${ }^{19}$ Ibid.

${ }^{20}$ Ibid., emphases in original.

21 Rancière, The lgnorant Schoolmaster, 71.

22 The fifth lesson Rancière dedicates to explaining the impossibility of institutionalizing universal teaching, the impossibility of making it a social program aimed at progress. See Rancière, The Ignorant Schoolmaster, 101-40.

23 Rancière, The Ignorant Schoolmaster, 90.

24 Ibid.

${ }^{25}$ Of course, Rancière is one figure in a much larger conversation among continental philosophers regarding the nature of community. His work is in many ways in tune with thinkers interested in some kind of community without community, some kind of inoperative community. See especially Maurice Blanchot, The Unavowable Community, trans. Pierre Joris (Barrytown, NY: Station Hill Press, 1988); Jean-Luc Nancy, The Inoperative Community, trans. Peter Connor, Lisa Garbus, Michael Holland, and Simona Sawhney (Minneapolis: University of Minnesota Press, 1991); and Giorgio Agamben, The Coming Community, trans. Michael Hardt (Minneapolis: University of Minnesota Press, 1993).

${ }^{26}$ Rancière, The Ignorant Schoolmaster, 98, emphasis in original. See also (emphasis again in original): "Equality is not given, nor is it claimed; it is practiced, it is verified" (137).

27 As Badiou has nicely put this point, Rancière takes as his task to think "the relation of a non-relation, or the non-relation conceived as a relation." Alain Badiou, “Jacques Rancière's Lessons: Knowledge and Power After the Storm," in The Adventure of French Philosophy, ed. and trans. Bruno Bosteels (New York: Verso, 2012), 103.

${ }^{28}$ Rancière, The Ignorant Schoolmaster, 90. 
29 Ibid. For further discussion, see Jacques Rancière, Hatred of Democracy, trans. Steven Corcoran (New York: Verso, 2006), 51-70; Rancière, The Ignorant Schoolmaster, 91, 125-26, 131-32.

30 Rancière, The Ignorant Schoolmaster, 91.

31 Ibid.

32 Rancière, The lgnorant Schoolmaster, 58.

33 This is perhaps clearest in the summary of the atomists' doctrines by Diogenes Laertius. See C. C. W. Taylor, The Atomists: Leucippus and Democritus, Fragments: A Text and Translation with a Commentary (Toronto: University of Toronto Press, 1999), 94-95.

${ }^{34}$ For Althusser's writings on the atomists-and on Epicurus in particular-see, again, Althusser, Philosophy of the Encounter, 163-207.

35 Rancière presents an argument against the equivalence of mind and brain in Rancière, The Ignorant Schoolmaster, 46-49.

${ }^{36}$ Rancière, The Ignorant Schoolmaster, 77.

37 For the original text, see Joseph Jacotot, Mélanges posthumes de philospohie panécastique (Paris: Imprimerie de Ducessois, 1841), 117. (Note that Rancière himself mis-cites the text, placing it on page 118. Note also that an edition of the Mélanges posthumes from a decade later, using the same pagination, can be accessed more easily: Joseph Jacotot, Mélanges posthumes de philospohie panécastique [Paris: Imprimerie Bonaventure et Ducessois, 1852].) The lines included here between parentheses appear in Rancière, The Ignorant Schoolmaster, 76-77.

38 Ibid., translation slightly altered.

39 These are Jacotot's words, cited in Rancière, The Ignorant Schoolmaster, 76.

40 Curiously, Rancière mis-cites his source for this second quotation, locating it within the same essay, "Politics," to be found in the Mélanges posthumes (he cites page 116). It does not appear there in either the 1841 or the 1852 edition, however. Instead, it appears in Jacotot's volume Droit et philosophie panécastique. See Joseph Jacotot, Enseignement universel: droit et philosophie panécastique (Paris: Paris: Imprimerie Bonaventure et Ducessois, 1852), 129.

41 Jacotot, Enseignement universel, 128.

42 Ibid., emphasis in original.

43 Ibid.

${ }^{44}$ See the testimonia gathered in Brad Inwood and L. P. Gerson, eds., The Epicurus Reader: Selected Writings and Testimonia, trans. Brad Inwood and L. P. Gerson

Journal of French and Francophone Philosophy | Revue de la philosophie française et de langue française Vol XXIII, No 2 (2015) | http://www.jffp.org | DOI 10.5195/jffp.2015.691 
(Indianapolis: Hackett, 1994), 47-64; and the discussion in Richard D. McKirahan, Philosophy Before Socrates: An Introduction with Texts and Commentary, 2nd ed. (Indianapolis: Hackett, 2010), 304-26. Jacotot seems to have been aware of this distinction, since speaks in the preceding paragraph of material vortices and of how such would "smother" intellectual emancipation. Jacotot, Droit et philosophie panécastique, 128.

45 See Jacques Rancière, Disagreement: Politics and Philosophy, trans. Julie Rose (Minneapolis: University of Minnesota Press, 1999), 34: “In the social order, there can be no vacuum. There is only ever the full, weights and counterweights. Politics is thus the name of nothing." Even more recently, interestingly, Rancière has used the same atomistic imagery to critique Gilles Deleuze, in whose work no Rancièrean community of equals forms, but "only atoms and groups of atoms, accidents and their incessant modifications," figured by Deleuze's image of "a wall of loose, uncemented stones." Jacques Rancière, The Flesh of Words: The Politics of Writing, trans. Charlotte Mandell (Stanford: Stanford University Press, 2004), 161-63.

46 Badiou would comment only briefly on atomism in Being and Event, leaving his earlier engagement largely behind. See Alain Badiou, Being and Event, trans. Oliver Feltham (New York: Continuum, 2006), 52-59. It must be noticed nonetheless that, despite using a distinct set of images to communicate his basic philosophical concepts, the continuity between Theory of the Subject and Badiou's fully mature work cannot be gainsaid. Although he utilizes atomism differently-if at all-in his most recent work, the use of atomistic language and imagery in Theory of the Subject remains relevant to the larger frame of Badiou's philosophical project.

47 One clear indication that the basic aim of Theory of the Subject has continued into Badiou's most recent work is signaled clearly by Badiou's retention of the term "materialist dialectic" from Theory of the Subject in the second volume of Being and Event: "After much hesitation, I have decided to name materialist dialectic the ideological atmosphere in which my philosophical undertaking conveys its most extreme tension." This fully mature presentation of the project demonstrates with particular force the continuing relevance of Badiou's earlier assessment of atomism. Alain Badiou, Logics of Worlds: Being and Event II, trans. Alberto Toscano (New York: Continuum, 2009), 3.

48 Badiou works this out in startling detail and systematicity over the course of the first two parts of Theory of the Subject. See Badiou, Theory of the Subject, 1-110.

${ }^{49}$ Badiou, Theory of the Subject, 24-25.

50 Badiou, Theory of the Subject, 55.

Journal of French and Francophone Philosophy | Revue de la philosophie française et de langue française Vol XXIII, No 2 (2015) | http://www.jffp.org | DOI 10.5195/jffp.2015.691 
51 G. W. F. Hegel, Science of Logic, trans. A. V. Miller (Atlantic Highlands, NJ: Humanities Press International, 1969), 166.

52 Badiou, Theory of the Subject, 56.

${ }^{53}$ Hegel, Science of Logic, 166.

54 Badiou, Theory of the Subject, 56.

55 Hegel, Science of Logic, 166.

56 Ibid. All but the last of these quotations from Hegel's Science of Logic appear directly in Badiou's discussion.

${ }^{57}$ Badiou, Theory of the Subject, 57, emphasis added.

58 Ibid.

59 Badiou develops this same nature/history schema more fully and more maturely in Badiou, Being and Event, 104-41, 173-98.

${ }^{60}$ Badiou, Metapolitics, 110.

61 lbid.

${ }^{62}$ Rancière, The Ignorant Schoolmaster, 13.

63 Rancière, The lgnorant Schoolmaster, 12.

64 The most succinct summary of the emancipatory operation of the ignorant master can be found at The Ignorant Schoolmaster, 13.

${ }^{65}$ Rancière, The Ignorant Schoolmaster, 108.

${ }^{66}$ Badiou, Theory of the Subject, 63.

67 Inwood and Gerson, The Epicurus Reader, 47. (The original text comes from Cicero's On Goals 1.18-20.)

68 Ibid. Lucretius not only claimed that the swerve was causeless, but also that it occurs "at quite indeterminate times and places." Lucretius, On the Nature of the Universe, trans. R. E. Latham (New York: Penguin Books, 1951), 66.

69 Karl Marx, "Notebooks on Epicurean Philosophy," in Karl Marx and Frederick Engels, Karl Marx, Frederick Engles: Collected Works, 50 vols. (New York: International Publishers, 1975-2005), 1:472.

70 Karl Marx, "Difference between the Democritean and Epicurean Philosophy of Nature," in Karl Marx and Frederick Engels, Karl Marx, Frederick Engles: Collected Works, 50 vols. (New York: International Publishers, 1975-2005), 1:46-53. Hegel himself, of course, did not find any real dialectical insights in this particular feature of atomism. See Hegel, Science of Logic, 167.

${ }^{71}$ Badiou, Theory of the Subject, 57, emphasis in original.

72 Badiou, Theory of the Subject, 58.

73 Ibid.

Journal of French and Francophone Philosophy | Revue de la philosophie française et de langue française Vol XXIII, No 2 (2015) | http://www.jffp.org | DOI 10.5195/jffp.2015.691 
${ }^{74}$ Badiou, Theory of the Subject, 59.

75 Badiou, Theory of the Subject, 61.

${ }^{76}$ Badiou develops the relationship between cause and consistency somewhat later in the book. See especially Theory of the Subject, 177-274.

77 The parallels between the atomistic swerve in Theory of the Subject and the event in Badiou's fully mature work are obvious. Swerve and event both mark an uprising within what otherwise would remain a static order of things. If the structural dialectic-or what Badiou later calls the constructivist orientation of thought-prevails, both swerve and event end up erased and transformation halted. Further, in both Theory of the Subject and Being and Event, swerve and event serve as the proper name of the void. See Badiou, Being and Event, 180.

${ }^{78}$ Rancière, The lgnorant Schoolmaster, 79, emphasis added.

${ }^{79}$ Rancière, The Ignorant Schoolmaster, 25.

80 The latter situation is, again, what Rancière calls "a pure relationship of will to will," one that puts out of play any hierarchy of intelligence (The Ignorant Schoolmaster, 13).

${ }^{81}$ Rancière, The Ignorant Schoolmaster, 79.

82 The title of the journal Rancière helped to edit during the early 1970s was Les Révoltes logiques, "Logical Revolts," most of which have been published in English in Rancière, Staging the People; and Jacques Rancière, The Intellectual and His People: Staging the People Volume 2, trans. David Fernbach (New York: Verso, 2012).

83 Badiou, Metapolitics, 110.

84 See, again, Rancière, The Politics of Literature, 183-205; and Rancière, Aesthetics and Its Discontents, 63-87. 